\title{
Efficacy and safety comparison of continuous glucose monitoring and self-monitoring of blood glucose in type 1 diabetes
}

\author{
Systematic review and meta-analysis
}

\author{
Piotr Wojciechowski ${ }^{1}$, Przemysław Ryś ${ }^{1}$, Anna Lipowska ${ }^{2,3}$, \\ Magdalena Gawęska', Maciej T. Małecki ${ }^{3,4}$ \\ 1 HTA Consulting, Kraków, Poland \\ 2 Emory University School of Medicine, Atlanta, Georgia, United States \\ 3 Department of Metabolic Diseases, Jagiellonian University, Medical College, Kraków, Poland \\ 4 Department of Metabolic Diseases, University Hospital, Kraków, Poland
}

\section{KEY WORDS}

continuous glucose monitoring, meta-analysis, systematic review, type 1 diabetes
Correspondence to:

Prof. Maciej T. Małecki, MD, PhD, Katedra Chorób Wewnętrznych,

Uniwersytet Jagielloński, Collegium Medicum, ul. Kopernika 15, 31-501 Kraków, Poland phone: + 48-12-424-83-05, fax: +48-12-421-97-86, e-mail: malecki_malecki@yahoo.com Received: September 3, 2011 Revision accepted: September 28, 2011 Conflict of interest: Przemysław Ryś have recently received consultant's fee from Medtronic Poland Sp. z o. 0., a producer of CGM systems.

Pol Arch Med Wewn. 2011; 121 (10): 333-344

Copyright by Medycyna Praktyczna Kraków 2011

\section{ABSTRACT}

INTRODUCTION Self-monitoring of blood glucose (SMBG) is a crucial element of clinical care in type 1 diabetes, but it may not provide adequate glucose control. A newer alternative approach is continuous glucose monitoring (CGM) system, which allows a more thorough metabolic control. However, the results of trials comparing CGM with SMBG are inconsistent.

OBJECTIVES Based on a systematic review and meta-analysis, we aimed to assess the efficacy and safety of various CGM systems compared with SMBG.

METHODS We searched major medical databases up to June 2011 for randomized controlled trials comparing CGM and SMBG in type 1 diabetes. Studies of at least 12-week duration were included. Weighted mean difference (WMD) or standardized mean difference (SMD) was calculated for continuous measures and dichotomous data were expressed as odds ratio (OR) or risk ratio.

RESULTS We identified 14 relevant trials including a total of 1268 type 1 diabetic patients, of whom 670 were randomized to the CGM group and 598 to the SMBG group. Patients using CGM had a greater decrease in hemoglobin $A_{1 c}\left(\mathrm{HbA}_{1 \mathrm{c}}\right)$ from baseline compared with those using SMBG (WMD $-0.26 \%$ [-0.34; $-0.19])$. We found that the magnitude of the effect was similar in the subset of children and adolescents (WMD $-0.25 \%[-0.43 ;-0.08]$ ) to that in adults (WMD $-0.33 \%[-0.46 ;-0.2])$. Only real-time devices for CGM improved glycemic control (WMD $-0.27 \%[-0.34 ;-0.19])$. The percentage of patients achieving target $\mathrm{HbA}_{1 \mathrm{c}}$ was higher in the CGM group (OR $2.14[1.41 ; 3.26]$ ). Pooled results from 4 studies revealed a reduction in hypoglycemic events in the CGM group (SMD $-0.32[-0.52 ;-0.13]$ ).

concLusions CGM, partcicularly its real-time system, has a favorable effect on glycemic control and decreases the incidence of hypoglycemic episodes in both adult and pediatric patients with type 1 diabetes.

INTRODUCTION The landmark Diabetes Control and Complications Trial (DCCT) established that intensive insulin therapy with either multiple daily injections (MDI) or continuous subcutaneous insulin infusion (CSII), resulting in lower hemo- globin $\mathrm{A}_{1 c}\left(\mathrm{HbA}_{1 \mathrm{c}}\right)$ levels compared with standard treatment in type 1 diabetic patients, prevents the occurrence and postpones the progression of microvascular complications..$^{1,2}$ Thus, maintaining near-normal glucose levels is a crucial 
component of diabetic care. While both the MDI and CSII methods help achieve treatment targets, they also increase the likelihood of hypoglycemic episodes. ${ }^{1}$ One of the key components of the intensive therapy approach in DCCT was self-monitoring of blood glucose (SMBG) performed by the patient with a glucose meter used to adjust the insulin dose. ${ }^{1}$ Currently recognized as the standard element of clinical care in type 1 diabetic subjects, SMBG is used in conjunction with intensive insulin therapy. ${ }^{3}$ However, its limitations may be responsible, at least partially, for failed glucose control in many patients. For example, SMBG restricts the available information to only a few daily measurements. Consequently, short-term hyperglycemia and asymptomatic hypoglycemic episodes may not be recorded by the glucose meter and thus escape the patient's attention, which may delay appropriate therapeutic intervention. ${ }^{4}$

Continuous glucose monitoring (CGM) systems, a newer alternative approach for patient glucose monitoring, use a sensor that is inserted subcutaneously to obtain interstitial fluid glucose values and provide a more complete picture of the patient's glucose profile. ${ }^{5}$ The first ambulatory CGM system was approved by the Food and Drug Administration (FDA) in 1999, and its use has significantly increased over the years. ${ }^{6,7}$ These devices, requiring regular calibration with glucose meter readings, can be used intermittently or continuously and are available in 2 forms: retrospective and, a newer one, real-time in combination with retrospective. The former allows the user to download past data and look for trends in glucose values, and the latter provides also a rapid feedback to the user..$^{8,9}$ Compared with SMBG, CGM systems allow a more thorough evaluation of daily glycemic fluctuations and assessment of their potential causes, and subsequently allow to perform appropriate adjustments to therapy. ${ }^{4}$ Additionally, new advances in technology have led to the combination of CGM and insulin pump devices, merging monitoring with therapy. ${ }^{10}$

Several individual studies comparing CGM with SMBG in type 1 diabetes have been published in recent years, but their results are inconsistent. Some of them demonstrated that CGM as compared with SMBG improved glycemic control, while others did not show differences in comparison with standard glucose meter reading. ${ }^{9}$ Thus, it is important to establish the true effect of CGM based on all the available published studies, because there has been no systematic review and meta-analysis comparing these 2 interventions that would take into account specific patient groups and different technological systems of CGM devices. Therefore, based on a systematic review and meta-analysis, we aimed to determine the efficacy and safety of CGM systems compared with SMBG in adult and pediatric populations with type 1 diabetes. Additionally, in subgroup analyses, we tested whether individual CGM sys- tems and schemes of their use (ongoing vs. intermittent) differ in terms of health benefits.

METHODS Search strategy An extensive search in MEDLINE, EMBASE, CENTRAL, Trip Database, and the Centre for Reviews and Dissemination was carried out with a very sensitive search strategy including terms grouped into 3 categories: population (e.g., diabetes, T1DM, hyperglycemia), intervention (e.g., glucose monitoring, glucose measurement, continuous glucose monitoring, CGM, CGMS), and study design (e.g., random, randomization, $\mathrm{RCT}$ ). Moreover, clinical trial registers, sources provided by agencies responsible for medical product approval (European Medicines Agency, FDA), and conference abstracts presented at international diabetic meetings (American Diabetes Association, European Association for the Study of Diabetes) were screened for most up-to-date studies. References from retrieved articles were also reviewed to identify potentially relevant papers that are not indexed in electronic medical databases.

Inclusion and exclusion criteria Randomized controlled trials (RCTs) were considered relevant if they compared CGM with SMBG in type 1 diabetic patients on an intensive insulin regimen with CSII or MDI. However, both study arms had to be well-matched with respect to the insulin regimen. There were no restrictions related to age, type of CGM systems, and schemes of their use; however, CGM readings had to be used by patients or professionals to adjust insulin doses or to modify diet therapy. Only studies of at least 12-week duration were included. Trials were excluded from the analysis if they 1) had no available full-text version of the publication; 2) included patients treated in an intensive care unit; 3 ) involved intraperitoneal administration of insulin; 4) assessed noninvasive systems of glucose monitoring; 5) included only new-onset type 1 diabetes; or 6) included pregnant women.

Study selection and quality assessment All abstracts identified in the systematic search were independently screened by 2 experienced reviewers in order to find relevant studies fulfilling the above criteria. Data was subsequently extracted independently by both analysts. Any disagreement between the reviewers was resolved by consensus or assistance of the third independent expert during verification based on the full texts. The quality of RCTs was assessed using the criteria proposed by Jadad et al. ${ }^{11}$

Outcome measures The following variables were examined: $\mathrm{HbA}_{1 c}$ change from baseline, $\mathrm{HbA}_{1 \mathrm{c}}$ at the end of the study, percentage of patients achieving target $\mathrm{HbA}_{1 c}$, and the number and duration of hypo- and hyperglycemic episodes. Furthermore, safety was assessed with respect to the risk of severe hypoglycemic events, keto- 


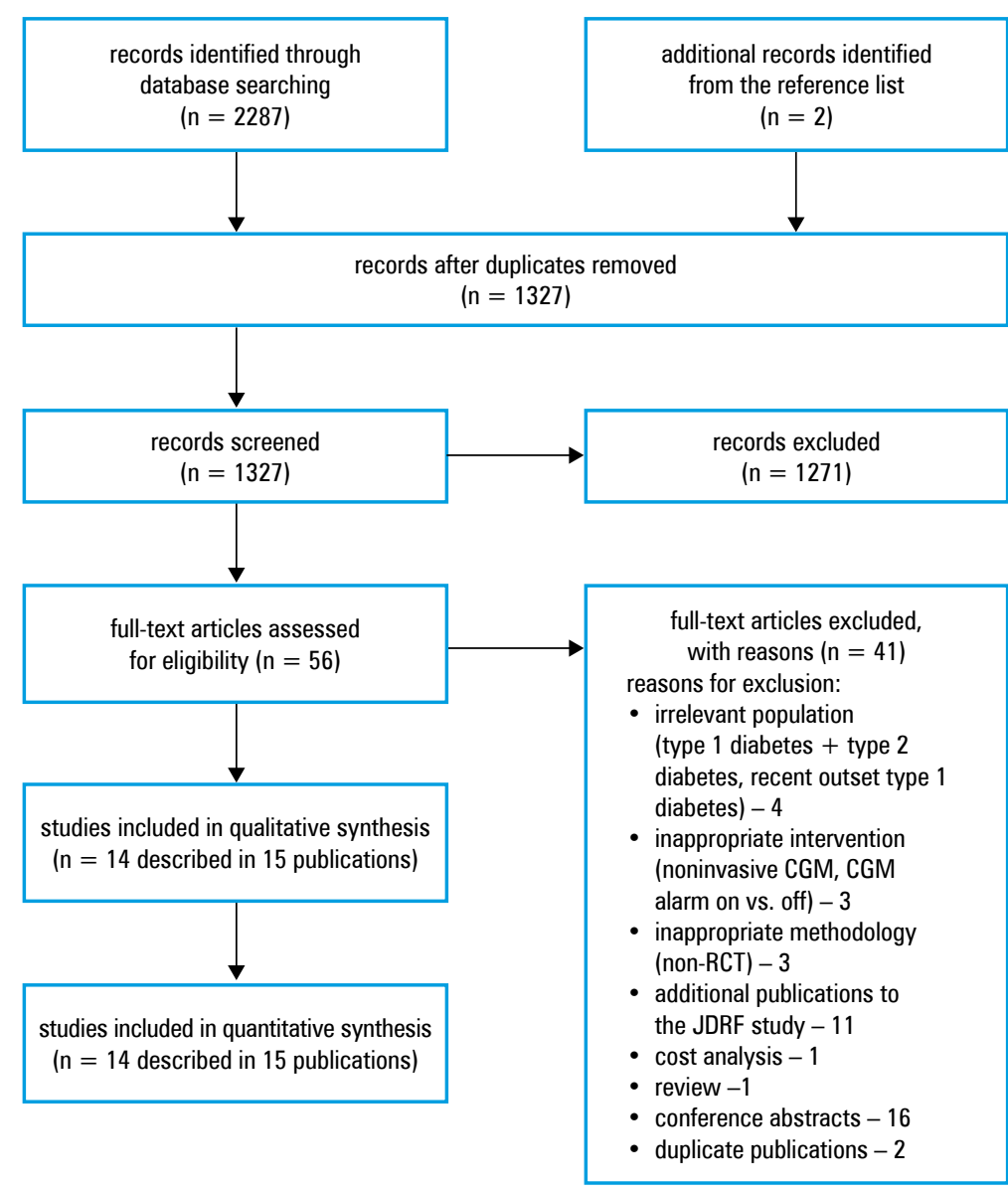

FIGURE 1 PRISMA diagram of study selection process

Abbreviations: CGM - continuous glucose monitoring, JDRF - Juvenile Diabetes Research Foundation, RCT - randomized controlled trial

acidosis, and adverse reactions at the sensor implantation site as well as CGM system errors.

Statistical analysis The effect measure for dichotomous data was the odds ratio (OR) or risk ratio (RR). However, if differences between the CGM and SMBG reached statistical significance, number needed to treat (NNT) or number needed to harm was calculated. Weighted mean difference (WMD) was calculated for continuous (measurable) outcomes. When different methods of evaluation were used for the same continuous endpoint and the units could not be unified, each individual result was standardized according to the Cohen's method by dividing difference in means by the pooled standard deviation and presented as a standardized mean difference (SMD)..$^{12}$ Wherever possible, results from individual studies were pooled in a meta-analysis. In case of statistical homogeneity between trials, the results were pooled with inverse variance (for continuous outcomes) or Mantel-Haenszel (for dichotomous outcomes) methods. Otherwise, the DerSimonian and Laird random effect model was performed both for continuous and dichotomous data. Significance of the overall effect was tested with the Fisher's z-test assuming $P<0.05$ as the level of significance. All results representing the effect size were stated with a $95 \%$ confidence interval (CI). Data analysis was performed with the Sophie v. 1.5 software for meta-analysis developed by HTA Consulting.

If pertinent values (mean with corresponding standard deviation, standard error, or CI) required for meta-analysis were not presented for each study arm separately, aggregated data (e.g., between group difference with $P$ value or $95 \%$ CI) were used. If standard deviation of change from baseline in $\mathrm{HbA}_{1 c}$ was missing, the precision of the value was estimated using correlation coefficient from studies reporting considerable details. $^{13}$

Data were stratified according to a prespecified criteria and a subgroup analysis was performed regarding patient age (children and adolescents, adults), level of glycemic control at baseline (measured by $\mathrm{HbA}_{1 \mathrm{c}}$ ), type of device (retrospective, real-time, sensor-augmented pump), and frequency of its use (ongoing, intermittent). We considered CGM measurement as ongoing when the device was continuously used at least 6 days per week, and intermittent when used for less than 6 days per week. ${ }^{14}$ Interactions were tested using the Cochrane Q-test for heterogeneity according to the Borenstein method. ${ }^{15}$ Publication bias was analyzed for $\mathrm{HbA}_{1 c}$ change from baseline with the Egger's test.

RESULTS Electronic search of medical databases was performed revealing 1325 records, of which 54 publications were considered potentially relevant and underwent further assessment. Screening of the references of the included studies identified 2 additional papers. Following a detailed examination based on full texts, 41 publications were excluded. Finally, 14 trials described in 15 publications fulfilled the inclusion criteria and were incorporated into this review (FIGURE 1)..$^{10,16-29}$

Study characteristics The studies enrolled a total of 1268 patients, of whom 670 were randomized to CGM and the remaining 598 patients were assigned to SMBG alone. The mean age ranged from 9 to 52 years. Seven trials included type 1 diabetic patients of all age groups, ${ }^{10,22,24-27,29}$ while the remaining studies enrolled children and adolescents ${ }^{16,18-21}$ or exclusively adults. ${ }^{17,28}$ Mean duration of diabetes ranged from 6 to 28 years, but this information was not provided in 2 trials. ${ }^{19,21}$ Populations of the included trials were heterogeneous with respect to glycemic control. Two trials enrolled only patients with good glycemic control $\left(\mathrm{HbA}_{1 c}<7.5 \%\right) .{ }^{27,29}$ Five studies included subjects with uncontrolled diabetes $\left(\mathrm{HbA}_{1 \mathrm{c}} \geq 8 \%\right),{ }^{10,16,22,26,28}$ while the remaining papers did not provide information whether they applied any restrictions to glycemic control ${ }^{17,19-21}$ or included both adequately and inadequately controlled patients. ${ }^{18,24,25}$ Mean baseline values of $\mathrm{HbA}_{1 \mathrm{c}}$ levels differed between the studies and ranged from $6.4 \%$ to $11.5 \%$.

In 3 trials, all patients received the CSII regimen, ${ }^{10,24,26} 2$ studies used the MDI regimen, ${ }^{17,19}$ 
TABLE 1 Characteristics of the included studies

\begin{tabular}{|c|c|c|c|c|c|c|c|}
\hline Study & $\begin{array}{l}\text { Age } \\
\text { group }\end{array}$ & $\begin{array}{r}\text { Study } \\
\text { arm }\end{array}$ & $\begin{array}{l}\text { No. of } \\
\text { patients }\end{array}$ & Age, $\mathrm{y}^{\mathrm{a}}$ & $\begin{array}{l}\text { Diabetes } \\
\text { duration, } \mathrm{y}^{\mathrm{a}}\end{array}$ & $\begin{array}{l}\text { Baseline } \\
\mathrm{HbA}_{1 \mathrm{c}^{\prime}} \% \mathrm{a}\end{array}$ & $\begin{array}{l}\text { Type of CGM } \\
\text { system }\end{array}$ \\
\hline \multirow{2}{*}{$\begin{array}{l}\text { Battelino } \\
\text { et al. }^{29}\end{array}$} & \multirow{2}{*}{$\begin{array}{l}\text { Ch\&A, } \\
\text { adults }\end{array}$} & CGM & 62 & $26(14)$ & $12(11)$ & $6.9(0.6)$ & \multirow{2}{*}{$\begin{array}{l}\text { Freestyle Navigator (Abbott } \\
\text { Diabetes Care) }\end{array}$} \\
\hline & & SMBG & 58 & $26(15)$ & $11(11)$ & $6.9(0.7)$ & \\
\hline \multirow{2}{*}{$\begin{array}{l}\text { Beck } \\
\text { et al. }{ }^{27}\end{array}$} & \multirow{2}{*}{$\begin{array}{l}\text { Ch\&A, } \\
\text { adults }\end{array}$} & CGM & 67 & $29(16)$ & $16(15)$ & $6.4(0.5)$ & \multirow[t]{2}{*}{ various CGM systems ${ }^{d}$} \\
\hline & & SMBG & 62 & $32(18)$ & $18(15)$ & $6.5(0.3)$ & \\
\hline \multirow{2}{*}{$\begin{array}{l}\text { Chase } \\
\text { et al. }{ }^{16}\end{array}$} & \multirow[t]{2}{*}{ Ch\&A, } & CGM & 5 & $15(2)$ & $6(1)$ & $10.0(0.7)$ & \multirow[t]{2}{*}{ MiniMed (Medtronic) } \\
\hline & & SMBG & 6 & $12(1)$ & $7(3)$ & $9.0(1.2)$ & \\
\hline \multirow{2}{*}{$\begin{array}{l}\text { Chico } \\
\text { et al. }{ }^{17}\end{array}$} & \multirow[t]{2}{*}{ adults } & CGM & 40 & $37(12)$ & $17(12)$ & $8.3(1.6)$ & \multirow[t]{2}{*}{ MiniMed (Medtronic) } \\
\hline & & SMBG & 35 & $41(10)$ & $21(10)$ & $8.0(1.4)$ & \\
\hline \multirow{2}{*}{$\begin{array}{l}\text { Cosson } \\
\text { et al. }{ }^{28}\end{array}$} & \multirow[t]{2}{*}{ adults } & CGM & 3 & $47(7)$ & $15(6)$ & $9.0(0.7)$ & \multirow{2}{*}{$\begin{array}{l}\text { GlucoDay (Menarini } \\
\text { Diagnostics) }\end{array}$} \\
\hline & & SMBG & 6 & $52(13)$ & $21(10)$ & $9.0(0.1)$ & \\
\hline \multirow{2}{*}{$\begin{array}{l}\text { Deiss } \\
\text { et al. }{ }^{19}\end{array}$} & \multirow[t]{2}{*}{ Ch\&A } & CGM & 15 & $10(2-16)^{b}$ & $2(0-7)^{b}$ & $7.8(1.2)$ & \multirow[t]{2}{*}{ MiniMed (Medtronic) } \\
\hline & & SMBG & 15 & $12(3-16)^{b}$ & $3(0-6)^{b}$ & $8.4(1.0)$ & \\
\hline \multirow{4}{*}{$\begin{array}{l}\text { Deiss } \\
\text { et al. }{ }^{22}\end{array}$} & \multirow{4}{*}{$\begin{array}{l}\text { Ch\&A, } \\
\text { adults }\end{array}$} & CGM & 54 & \multirow{4}{*}{$\begin{array}{r}\text { Ch\&A: } 14 \\
(8-19)^{\mathrm{b}} \\
\text { adults: } 39 \\
(19-60)^{\mathrm{b}}\end{array}$} & \multirow[t]{4}{*}{ NA } & $9.5(1.1)$ & \multirow{4}{*}{$\begin{array}{l}\text { Guardian-RT MiniMed } \\
\text { (Medtronic) }\end{array}$} \\
\hline & & CGM & 54 & & & $9.6(1.2)$ & \\
\hline & & & & & & & \\
\hline & & SMBG & 54 & & & $9.7(1.3)$ & \\
\hline \multirow{2}{*}{$\begin{array}{l}\text { Hirsch } \\
\text { et al. }{ }^{24}\end{array}$} & \multirow{2}{*}{$\begin{array}{l}\text { Ch\&A, } \\
\text { adults }\end{array}$} & CGM & 66 & $33(15)$ & $21(12)$ & $8.5(0.8)$ & \multirow{2}{*}{$\begin{array}{l}\text { Paradigm } 722 \text { MiniMed } \\
\text { (Medtronic) }\end{array}$} \\
\hline & & SMBG & 72 & $33(16)$ & $17(10)$ & $8.4(0.6)$ & \\
\hline \multirow{2}{*}{$\begin{array}{l}\text { Lagarde } \\
\text { et al. }{ }^{20}\end{array}$} & \multirow[t]{2}{*}{ Ch\&A } & CGM & 18 & $10(3)$ & $5(3)$ & $8.4(1.0)$ & \multirow[t]{2}{*}{ MiniMed (Medtronic) } \\
\hline & & SMBG & 9 & $14(3)$ & $4(2)$ & $8.8(0.9)$ & \\
\hline \multirow{2}{*}{$\begin{array}{l}\text { Ludvigsson } \\
\text { et al. } .^{18}\end{array}$} & Ch\&A & CGM & 16 & $13(3)^{c}$ & $7(4)^{c}$ & $8.0(1.1)^{c}$ & MiniMed (Medtronic) \\
\hline & & SMBG & 16 & & & & \\
\hline O'Connell & Ch\&A, & CGM & 31 & $23(9)$ & $11(8)$ & $7.3(0.6)$ & Paradigm RT MiniMed \\
\hline et al. ${ }^{26}$ & adults & SMBG & 31 & $23(8)$ & $9(7)$ & $7.5(0.7)$ & ronic) \\
\hline Raccah & Ch\&A, & CGM & 55 & $28(15)$ & $11(9)$ & $9.1(1.3)$ & Paradigm RT MiniMed \\
\hline & adults & SMBG & 60 & $29(17)$ & $12(9)$ & $9.3(1.2)$ & (Medtronic) \\
\hline Tamborlane & Ch\&A, & CGM & 165 & $24(14)$ & $12(8)$ & $7.9(0.7)$ & various CGM systems $^{d}$ \\
\hline et al..$^{25}$ & adults & SMBG & 157 & & & $7.8(0.7)$ & \\
\hline Yates & Ch\&A & CGM & 19 & $15^{\mathrm{e}}$ & NA & $8.2(0.9)$ & MiniMed (Medtronic) \\
\hline et al. ${ }^{21}$ & & SMBG & 17 & $14^{\mathrm{e}}$ & & $7.9(0.9)$ & \\
\hline
\end{tabular}

a mean (SD), if not otherwise stated

b median (range)

c data of 27 patients

d Paradigm RT Minimed (Medtronic), DexCom Seven (DexCom), or Freestyle Navigator (Abbott Diabetes Care)

e median

and the remaining 9 publications stated that insulin could be administered either by an insulin pump or by multiple injections. ${ }^{16,18,20-22,25,27-29}$ A combination device composed of an insulin pump and CGM system (sensor-augmented pump) was used in 5 trials; ${ }^{10,24-27}$ however, only in 3 studies it was available to all patients in the CGM group. ${ }^{10,24,26}$

Apart from differences regarding the manufacturer (Abbott, Medtronic, DexCom, Menarini Diagnostics), studies were also heterogeneous with respect to the reading type and continuity of measurement. In 6 studies, CGM was used to monitor glucose levels in an ongoing manner throughout the study period. ${ }^{10,24-27,29}$ Intermittent methods of glucose measurement were applied in 7 subsequent studies, ranging in frequency from a single 72-hour reading at the beginning of the study ${ }^{17}$ to a sequence of 6 readings performed monthly corresponding to up to 18 days of measurement per month. ${ }^{16}$ One remaining publication described a 3-armed trial designed to compare both continuous and intermittent CGM with each other and with SMBG. ${ }^{22}$

Eight studies offered real-time glucose readings, ${ }^{10,22,24-29}$ while the remaining 6 provided only a retrospective method of data analysis. ${ }^{16-21}$ The duration of follow-up never exceeded 26 weeks. 


\begin{tabular}{|c|c|c|c|c|c|c|c|}
\hline $\begin{array}{l}\text { Continuity of CGM } \\
\text { reading }\end{array}$ & $\begin{array}{l}\text { Reading } \\
\text { type }\end{array}$ & $\begin{array}{l}\text { Insulin } \\
\text { regimen }\end{array}$ & $\begin{array}{l}\text { Study } \\
\text { duration, mo }\end{array}$ & $\begin{array}{l}\text { Data } \\
\text { analysis }\end{array}$ & $\begin{array}{l}\text { Allocation } \\
\text { concealment }\end{array}$ & Discontinuation, \% & Jadad \\
\hline ongoing & $\mathrm{RT}$ & CSII, MDI & 6 & $\mathrm{mlTT}$ & YES & 16 & $3 / 5$ \\
\hline ongoing & RT & CSII, MDI & 6 & ITT & unclear & 2 & $3 / 5$ \\
\hline $\begin{array}{l}\text { intermittent } \\
\qquad(6 \times \leq 72 \mathrm{~h} / \mathrm{mo})\end{array}$ & RETRO & CSII, MDI & 3 & ITT & unclear & 1 & $2 / 5$ \\
\hline $\begin{array}{l}\text { intermittent } \\
(72 \mathrm{~h} \text { in } 0 \mathrm{mo})\end{array}$ & RETRO & MDI & $2-3$ & NA & unclear & NA & $1 / 5$ \\
\hline $\begin{array}{l}\text { intermittent } \\
(2 \times 48 \mathrm{~h} \text { in } 0 \\
\text { and } 3 \mathrm{rd} \mathrm{mo})\end{array}$ & RT & CSII, MDI & 3 & PP & yes & NA & $3 / 5$ \\
\hline $\begin{array}{l}\text { intermittent } \\
(72 \mathrm{~h} \text { in } 0,3 \mathrm{rd} \text {, and } \\
6 \text { th } \mathrm{mo})\end{array}$ & RETRO & MDI & $\begin{array}{l}2 \times 3 \\
\quad(\text { cross-over) }\end{array}$ & ITT & unclear & NA & $1 / 5$ \\
\hline ongoing & $\mathrm{RT}$ & CSII, MDI & 3 & PP & unclear & 5 & $1 / 5$ \\
\hline \multicolumn{8}{|l|}{$\begin{array}{l}\text { intermittent } \\
(2 \times 72 \text { h every } \\
2 \mathrm{wk})\end{array}$} \\
\hline \multicolumn{8}{|l|}{-} \\
\hline ongoing & RT & CSII & 6 & PP & unclear & 6 & $1 / 5$ \\
\hline $\begin{array}{l}\text { intermittent } \\
\text { (72 h in } 0,2 \text { nd, and } \\
\text { 4th mo) }\end{array}$ & RETRO & CSII, MDI & 6 & ITT & yes & 0 & $3 / 5$ \\
\hline $\begin{array}{l}\text { intermittent } \\
\text { (72 h every } \\
2 \text { wk) }\end{array}$ & RETRO & CSII, MDI & $\begin{array}{l}2 \times 3 \\
\quad \text { (cross-over) }\end{array}$ & $\mathrm{PP}$ & unclear & 16 & $1 / 5$ \\
\hline ongoing & RT & CSII & 3 & PP & yes & 11 & $3 / 5$ \\
\hline ongoing & $\mathrm{RT}$ & CSII & 6 & mITT, PP & unclear & 17 & $1 / 5$ \\
\hline ongoing & RT & CSII, MDI & 6 & ITT & unclear & 2 & $3 / 5$ \\
\hline $\begin{array}{l}\text { intermittent } \\
\text { (72 h every } \\
3 \mathrm{wk})\end{array}$ & RETRO & CSII, MDI & 3 & $\mathrm{mlTT}$ & yes & 8 & $3 / 5$ \\
\hline
\end{tabular}

Abbreviations: Ch\&A - children and adolescents, CSII - continuous subcutaneous insulin infusion, ITT - intention-to-treat analysis, MDI - multiple daily injections, mITT - modified ITT, NA - not available, PP - per protocol analysis, RETRO - retrospective, RT - real-time, SD - standard deviation, SMBG self-monitoring of blood glucose, others - see FIGURE 1

In 6 studies, patients assigned to the SMBG group wore blinded CGM systems only to collect data on the time spent in hypo- and hyperglycemia, but not for insulin dose modification. $10,19,20,24,27,29$

All studies were specified as randomized, open-label with parallel or cross-over design. However, the double-blind method could only be employed in retrospective CGM. The randomization method was described in all but 3 studies, ${ }^{10,16,17}$ while adequate allocation concealment was provided in only 5 trials. ${ }^{20,21,26,28,29}$ Intention-to-treat analysis based on all randomized patients was performed in 5 trials, ${ }^{16,19,20,25,27}$ while the remaining studies applied either modified intention-to-treat analysis based on patients with available recordings, ${ }^{10,21,29}$ or per-protocol analysis including only those who completed the full study period (TABLE 1). 18,22,24,26,28

Glycemic control $\mathrm{HbA}_{1 c}$ change from baseline was reported in 14 studies included in the analysis. Five studies showed a statistically significant improvement in favor of CGM as compared with SMBG, and the remaining 9 did not demonstrate a difference between the groups. A quantitative accumulation revealed that patients using CGM had a significantly greater decrease in $\mathrm{HbA}_{1 c}$ from baseline compared with the control group 


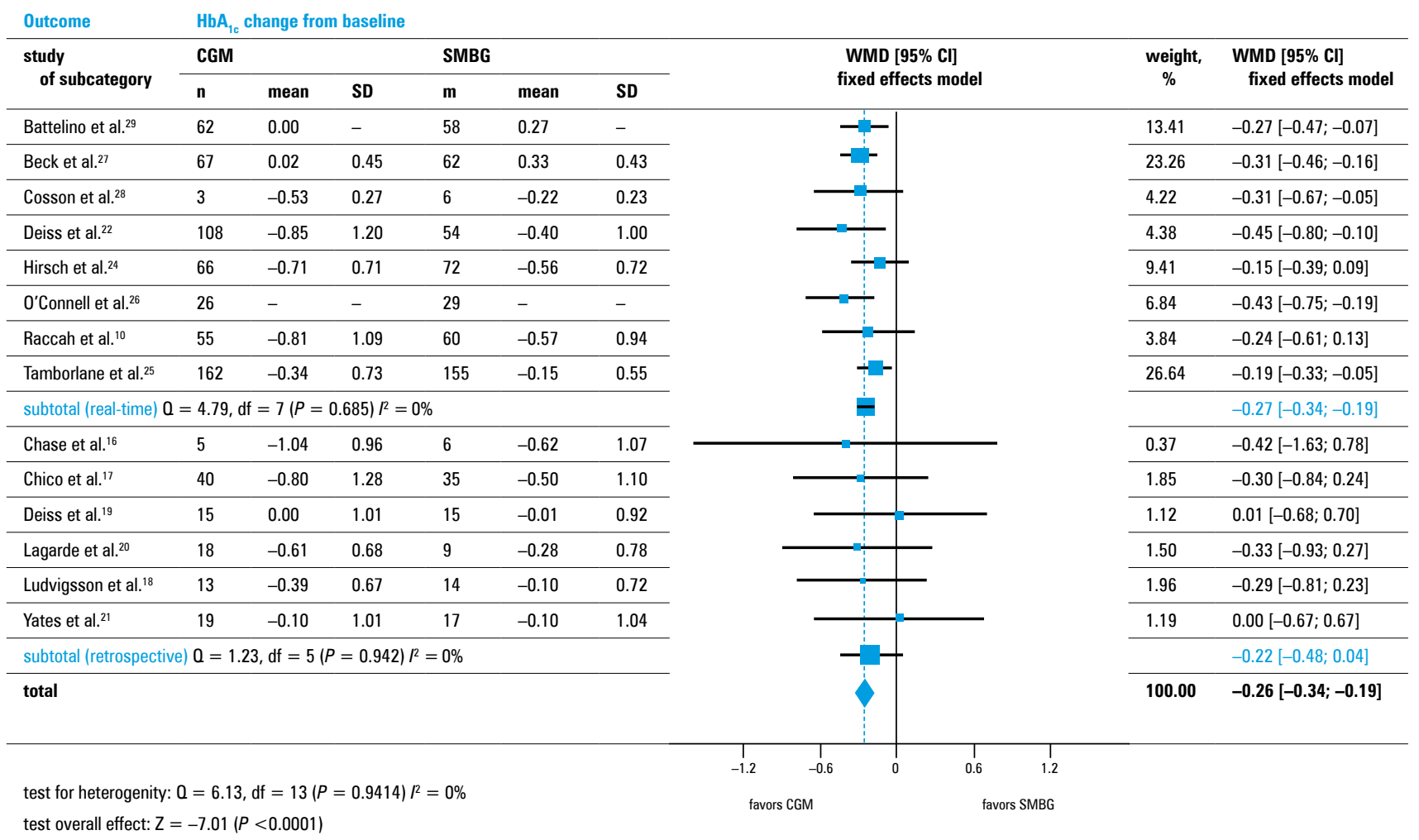

FIGURE $2 \quad \mathrm{HbA}_{1 \mathrm{c}}$ change from baseline for the comparison of CGM and SMBG - data stratified according to the type of glucose reading Abbreviations: $\mathrm{Cl}$ - confidence interval, $\mathrm{HbA}_{1 \mathrm{c}}$ - hemoglobin $\mathrm{A}_{1 \mathrm{c}^{\prime}}$ WMD - weighted mean difference, others - see FIGURE 1 and TABLE 1
(WMD -0.26 [-0.34; -0.19]) with no statistical heterogeneity between the studies (FIGURE 2). Stratified analysis showed that this difference was significant for both ongoing and intermittent types of CGM use. Real-time devices for continuous glucose monitoring improved glycemic control when compared with SMBG (WMD -0.27 [-0.34; -0.19]), while no significant difference was noted for retrospective CGM systems (WMD -0.22 [-0.48; 0.04]). However, the magnitude of this effect did not differ between real-time and retrospective CGM ( $P$ value for interaction 0.744). Furthermore, a significant decrease in $\mathrm{HbA}_{1 c}$ compared with the SMBG group was observed in patients who used both types of CGM systems: sensor-augmented pumps and separate sensors displaying values in real time (FIGURE 4). We found a similar magnitude effect of CGM use in the subset of children and adolescents (WMD -0.25 [-0.43;-0.08]) as was observed for adult patients (FIGURES 3 and 4). Efficacy of CGM did not differ significantly between the subgroups representing various levels of baseline $\mathrm{HbA}_{1 c}$ (FIGURE 4). No evidence for publication bias was found $(P=0.8070)$.

The benefit of CGM on glycemic control was also confirmed in the analysis of $\mathrm{HbA}_{1 c}$ levels at the end of the trials. Meta-analysis of 12 trials demonstrated that patients in the CGM group had lower end-of-treatment $\mathrm{HbA}_{1 c}$ values when compared with the SMBG group (WMD -0.22 [-0.42; -0.02]). However, there was a high degree of heterogeneity in this estimate, likely caused by differences in baseline $\mathrm{HbA}_{1 c}$ between the groups observed in small studies. A significant advantage in comparison with SMBG was observed for real-time
CGM (WMD -0.33 [-0.48; -0.18]), but not for retrospective devices (WMD -0.08 [-0.47; 0.31]).

Four studies reported numbers of patients who achieved predefined target $\mathrm{HbA}_{1 c}$ levels. In 3 trials $^{24-26}$ the target was defined as $\leq 7 \%$, and in 1 study $^{21}$ the threshold was a bit higher $(\leq 7.5 \%)$. Pooled results of all 4 trials indicated that significantly more subjects in the CGM group achieved predefined target levels of $\mathrm{HbA}_{1 c}$ when compared with those using SMBG only (OR 2.14 [1.41; 3.26]; $\mathrm{NNT}_{3-6 \mathrm{mo}} 7.91$ [5.16; 16.94]). Similar results were also obtained in the meta-analysis of 3 studies with target $\mathrm{HbA}_{1 c} \leq 7 \%$. Additionally, in 1 study ${ }^{25}$ a significantly greater percentage of patients achieved at least a $10 \%$ reduction of $\mathrm{HbA}_{1 \mathrm{c}}$ in the CGM group as compared with SMBG (OR 2.95 [1.53; 5.71]; $\left.\mathrm{NNT}_{6 \mathrm{mo}} 7.40[4.70 ; 17.43]\right)$.

Hyperglycemia Six trials assessed endpoints attributable to the occurrence of hyperglycemia. Time spent in hyperglycemia at the end of treatment was assessed in 3 studies, none of which demonstrated a significant difference between CGM and SMBG. Meta-analysis was unfeasible due to differences in definitions and outcome presentations. Three trials reported a change from baseline in hyperglycemia duration. In 2 of them, a significant reduction in favor of CGM was observed, while no statistically significant difference between the groups was reported in 1 study (TABLE 2).

Hypoglycemia Hypoglycemic outcomes were reported in 10 trials. However, the data were presented in a different manner, namely, as the number of any hypoglycemic episodes during the study, percentage of patients with at least 1 episode of 
TABLE 2 Duration of hyper- and hypoglycemia for comparison of CGM with SMBG

\begin{tabular}{|c|c|c|c|c|c|c|}
\hline Outcome & Definition & $\begin{array}{l}\text { Study } \\
\text { duration, mo }\end{array}$ & $\begin{array}{l}\text { No. of } \\
\text { studies }\end{array}$ & $\begin{array}{l}\text { No. of } \\
\text { patients }\end{array}$ & $\begin{array}{l}\text { Estimate } \\
\qquad[95 \% \mathrm{Cl}]\end{array}$ & References \\
\hline \multicolumn{7}{|l|}{ hyperglycemia } \\
\hline $\begin{array}{l}\text { time spent in } \\
\text { hyperglycemia }\end{array}$ & $\begin{array}{l}\geq 10.0 \mathrm{mmol} / \mathrm{l} ; \\
>13.9 \mathrm{mmol} / \mathrm{l}\end{array}$ & 6 & 3 & 198 & NS in each trial & $19,26,29$ \\
\hline \multirow[t]{5}{*}{$\begin{array}{l}\text { change of time spent } \\
\text { in hyperglycemia }\end{array}$} & $\begin{array}{c}>10.0 \mathrm{mmol} / \mathrm{l} \\
(\mathrm{min} / \mathrm{day})\end{array}$ & 6 & 1 & 322 & $\begin{array}{l}\text { MD }-60.52 \\
\quad[-101.35 ;-19.69]^{\mathrm{a}}\end{array}$ & 23,25 \\
\hline & $\begin{array}{l}>10.5 \mathrm{mmol} / \mathrm{l} \\
\text { (h/day) }\end{array}$ & 6 & 1 & 100 & $\begin{array}{l}\mathrm{MD}-2.80 \\
\quad[-4.52 ;-1.08]^{\mathrm{a}}\end{array}$ & 10 \\
\hline & $\begin{array}{c}>13.9 \mathrm{mmol} / \mathrm{l} \\
\text { (min/day) }\end{array}$ & 6 & 1 & 322 & $\begin{array}{l}\text { MD }-29.15 \\
\quad[-45.37 ;-12.92]^{\mathrm{a}}\end{array}$ & 23,25 \\
\hline & $\begin{array}{c}>10.0 \mathrm{mmol} / \mathrm{l} \\
\text { (min/day) }\end{array}$ & 6 & 1 & 126 & NS & 27 \\
\hline & $\begin{array}{c}>13.9 \mathrm{mmol} / \mathrm{l} \\
(\mathrm{min} / \mathrm{day})\end{array}$ & 6 & 1 & 126 & NS & 27 \\
\hline \multicolumn{7}{|l|}{ hypoglycemia } \\
\hline \multirow[t]{5}{*}{$\begin{array}{l}\text { time spent in } \\
\text { hypoglycemia }\end{array}$} & $\begin{array}{l}<3.1 \mathrm{mmol} / \mathrm{l} \\
\text { (h/day) }\end{array}$ & 6 & 1 & 116 & $\begin{array}{l}\mathrm{MD}-0.19 \\
\quad[-0.34 ;-0.04]^{\mathrm{a}}\end{array}$ & 29 \\
\hline & $\begin{array}{l}<3.5 \mathrm{mmol} / \mathrm{l} \\
\text { (h/day) }\end{array}$ & 6 & 1 & 116 & $\begin{array}{l}\mathrm{MD}-0.49 \\
\quad[-0.93 ;-0.05]^{\mathrm{a}}\end{array}$ & 29 \\
\hline & $\begin{array}{l}<3.9 \mathrm{mmol} / \mathrm{l} \\
\text { (h/day) }\end{array}$ & 6 & 2 & 143 & $\begin{array}{l}\text { WMD }-0.01 \\
{[-1.49 ; 1.46]}\end{array}$ & 20,29 \\
\hline & $\begin{array}{c}<3.3 \mathrm{mmol} / \mathrm{l} \\
(\mathrm{min} / \text { day })\end{array}$ & 3 & 1 & 30 & NS & 19 \\
\hline & $\begin{array}{l}\leq 3.9 \mathrm{mmol} / \mathrm{l} \\
(\% \text { of observation } \\
\text { period) }\end{array}$ & 3 & 1 & 52 & NS & 26 \\
\hline $\begin{array}{l}\text { change of time spent } \\
\text { in hypoglycemia }\end{array}$ & $\begin{array}{l}\leq 2.8 \mathrm{mmol} / \mathrm{l} ; \\
\leq 3.3 \mathrm{mmol} / ; \\
\leq 3.9 \mathrm{mmol} / \mathrm{l} \\
\text { (min/day) }\end{array}$ & 6 & 3 & 548 & NS in each trial & $\begin{array}{l}10,23,25 \\
27\end{array}$ \\
\hline
\end{tabular}

a statistically significant

Abbreviations: MD - mean difference, NS - nonsignificant, others - see FIGURE 2

severe hypoglycemia, and time spent in hypoglycemia. Four studies provided information on the frequency of hypoglycemic episodes. Two of them reported a benefit of CGM use, while the remaining 2 did not reveal any significant differences between the groups. Pooled results of those 4 studies demonstrated a significant reduction of hypoglycemic events in the CGM group as compared with the SMBG group (SMD -0.32 [-0.52; $-0.13]$ ). No heterogeneity between the studies was noted (FIGURE 5). The difference remained sig nificant even after the exclusion of the only trial in which glucose reading in the CGM group was performed retrospectively (WMD -0.24 [-0.38; -0.10])..$^{20}$ In 1 study, which reported change from baseline in the frequency of hypoglycemic episodes, no significant difference between CGM and SMBG was observed (mean difference 0.00 $[-0.32 ; 0.32]) .^{10}$

Percentage of patients with severe hypoglycemic episodes was reported in 5 studies, none of which revealed any statistically significant differences between the groups. Pooled results of all 4 studies ${ }^{18,25,27,29}$ confirmed that cumulative risk of severe hypoglycemic episodes was comparable in both groups (6.5\% vs. 8.0\%; RR 0.83 [0.47; $1.45])$ with no heterogeneity $\left(\mathrm{I}^{2}=0 \% ; P=0.9869\right)$.
Similar results were obtained from the meta-analysis of 3 studies ${ }^{24,25,27}$ providing data on severe hypoglycemic episodes requiring assistance (4.4\% vs. $2.7 \%$; RR 1.63 [0.69; 3.83]).

Of 4 studies that reported time spent in hypoglycemia at the end of treatment, 1 revealed improvement in the CGM group regardless of the hypoglycemia definition ( $<70 \mathrm{mg} / \mathrm{dl},<63 \mathrm{mg} / \mathrm{dl}$, or $<55 \mathrm{mg} / \mathrm{dl}$ ), while the remaining $3 \mathrm{did}$ not demonstrate significant differences between the groups. Meta-analysis was feasible only for 2 studies and showed no difference in the mean daily time spent in hypoglycemia < $70 \mathrm{mg} / \mathrm{dl}$ (WMD -0.01 [-1.49; 1.46]). No differences with respect to a change of time spent in hypoglycemia were presented in any of the 3 studies reporting this outcome (TABLE 2).

Safety Data on the rate of adverse events were available only in a few trials and comprised mainly mild reactions at the sensor implantation site in the CGM group. In 1 study, which enrolled 30 patients, $23 \%$ of the cases reported redness, $16 \%$ redness and itching, and 1 patient (1\%) experienced painful itching. ${ }^{19}$ Severity of pain associated with sensor implantation was assessed in another trial on the basis of tolerability questionnaires. More than half of the patients (54.4\%) 


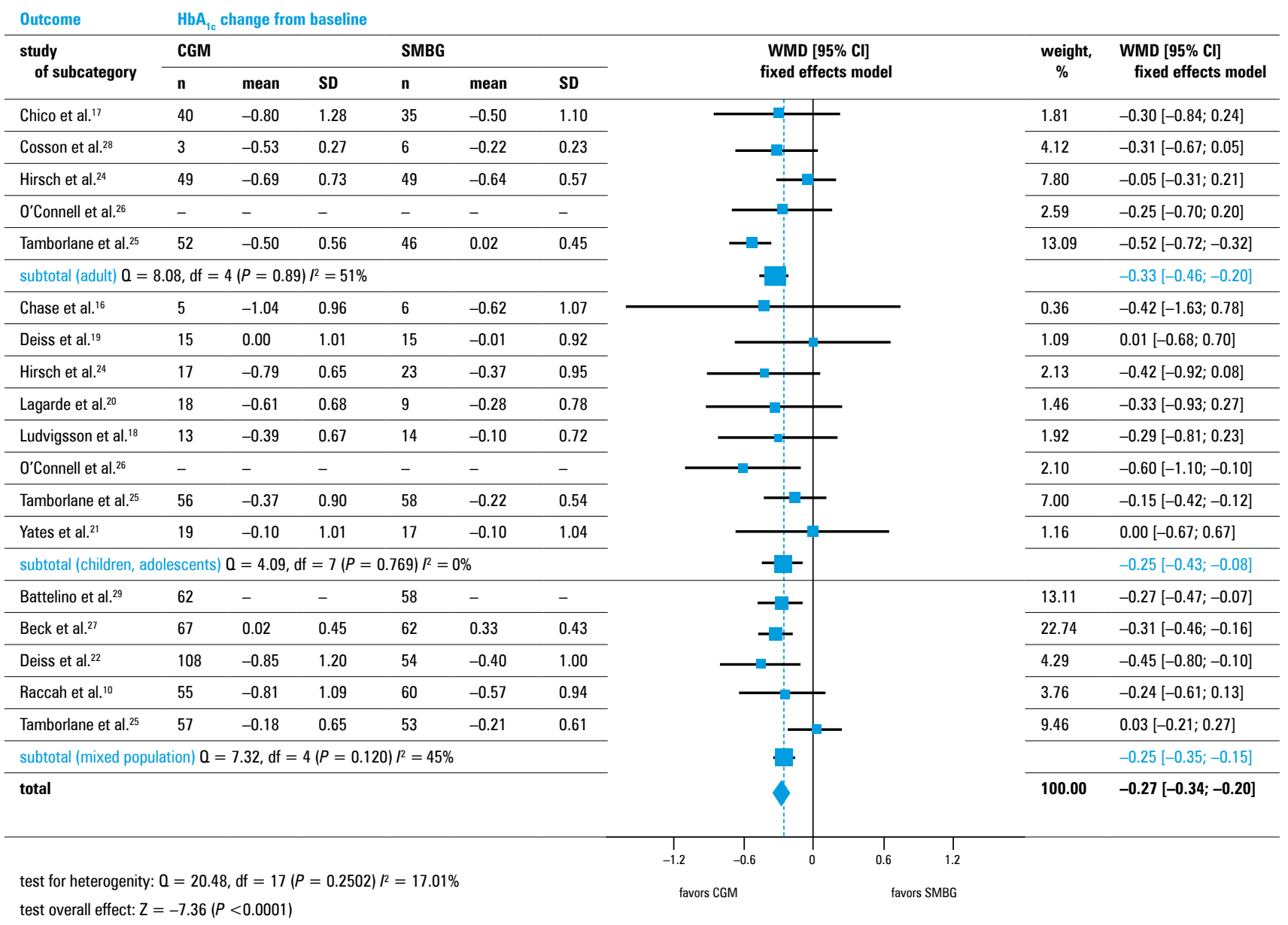

FIGURE $3 \quad \mathrm{HbA}_{1 \mathrm{c}}$ change from baseline for the comparison of CGM and SMBG - data stratified according to the age group Abbreviations: see FIGURE 1, FIGURE 2, and TABLE 1

FIGURE $4 \quad \mathrm{HbA}_{1 \mathrm{c}}$ change from baseline subgroup analyses for the comparison of CGM and SMBG

Abbreviations: see FIGURE 1, FIGURE 2, and TABLE 1

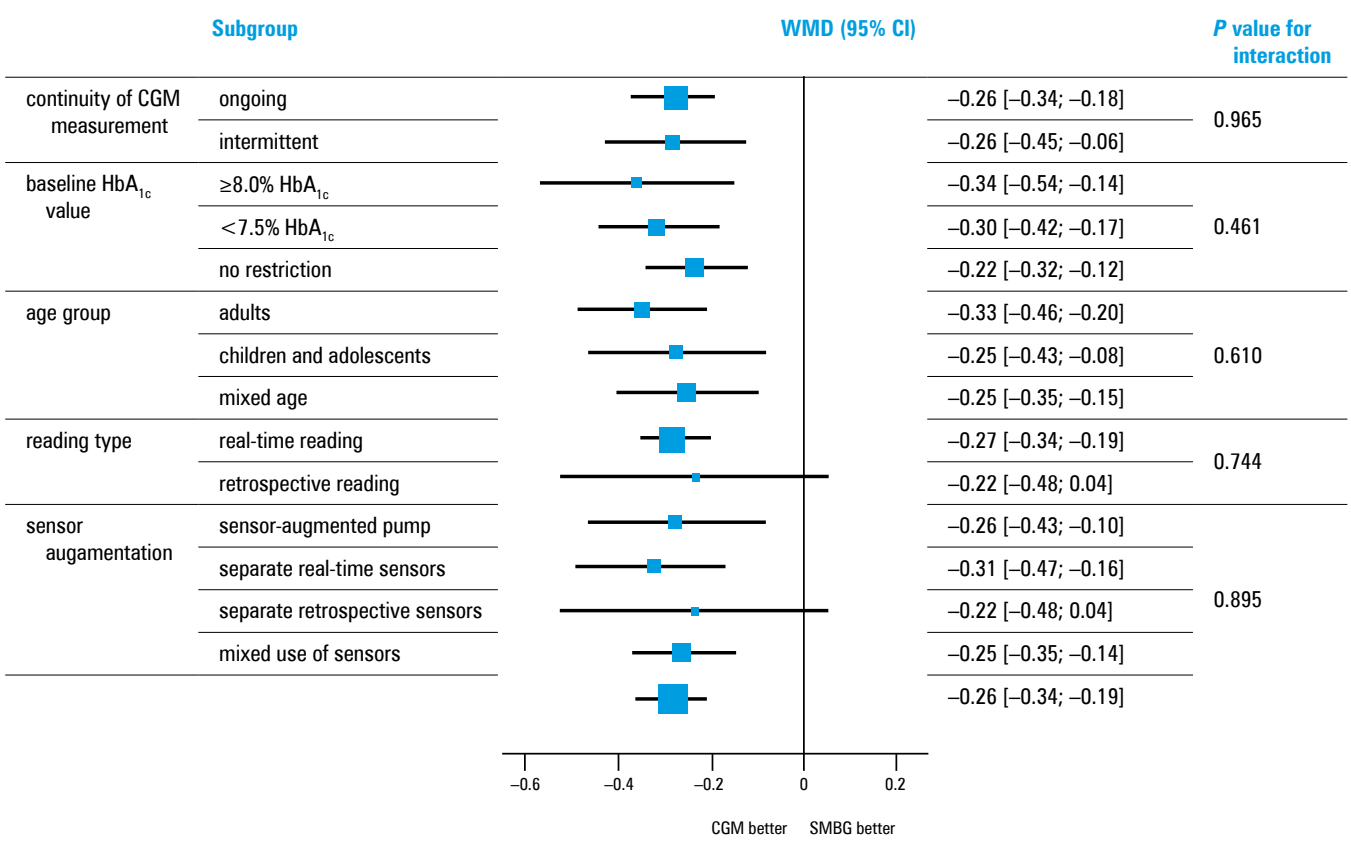

did not feel any pain during implantation, $38.2 \%$ reported mild pain, $5.8 \%$ moderate, and only 1 (1.4\%) experienced severe pain. ${ }^{28}$ Other reported adverse reactions were infrequent and consisted of individual cases of skin abscess formation or cellulitis. ${ }^{24,25}$ Three studies reported technical problems related to the use of CGM including register interruption for several hours or days, device errors that precluded data storage, and alarms going off as a result of major discrepancies between sensor and glucose meter values. ${ }^{17,18,26}$ The risk 


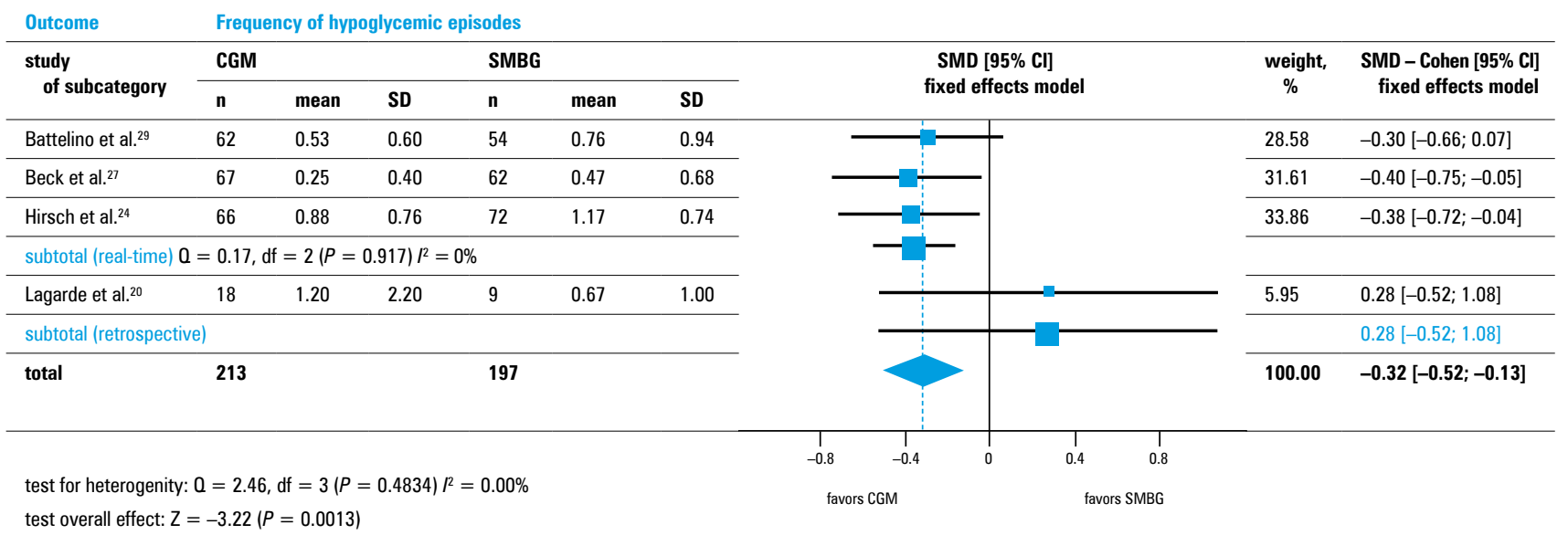

FIGURE 5 Frequency of hypoglycemic episodes for the comparison of CGM and SMBG Abbreviations: see FIGURE 1, FIGURE 2, and TABLE 1 of ketoacidosis episodes was rare and comparable in both groups ( $1 \%$ vs. $0.3 \%$; RR 1.58 [0.38; $6.54]){ }^{21,24,25,29}$

DISCUSSION Despite enormous progress in the medical care of type 1 diabetic patients, it is still not possible to achieve full normalization of their glucose levels. However, step by step, this ultimate goal is being achieved. One of the elements of this progress is the introduction to the medical market of a new generation of devices that allow continuous glucose monitoring. Our meta-analysis based on a systematic review revealed that CGM use significantly lowers $\mathrm{HbA}_{1 c}$ as compared with SMBG. This is concordant with a reduction of time spent in hyperglycemia demonstrated in 2 of 3 trials reporting this outcome. While the magnitude of this effect on $\mathrm{HbA}_{1 \mathrm{c}}$ may provoke questions on their clinical relevance, it should be noted that observational analyses showed a continuous complication risk reduction accompanying a decrease in $\mathrm{HbA}_{1 c}$ levels in type 1 diabetic patients. ${ }^{30}$ This moderate decrease in $\mathrm{HbA}_{1 \mathrm{c}}$ in our study should be considered in the context of a concomitant reduction in the frequency of hypoglycemic events. Improvement with regard to both of these measures, which usually demonstrate a reversible correlation, ${ }^{31,32}$ indicates that CGM systems may offer a comprehensive and clinically relevant benefit in type 1 diabetes.

Our stratified analyses showed that results favoring CGM over SMBG were consistent across different age groups and different levels of initial glycemic control. The effect of CGM on patients of various ages has been a topic of recent debate. The Juvenile Diabetes Research Foundation (JDRF) Continuous Monitoring Study Group found that CGM improved $\mathrm{HbA}_{1 c}$ in adult patients who were 25 years or older, while no differences were observed in comparison with SMBG among individuals under 25 years of age. ${ }^{25}$ Based on the results from the JDRF study, current clinical guidelines recommend CGM for improving glycemic control mainly in the adult population with type 1 diabetes. In our analysis, we categorized adults as individuals over 18 years old, children or adolescents as those below 18 years of age, and a mixed population was considered if studies did not separate data for different age groups. For the adult population, the results were consistent with the previous studies, demonstrating a decrease in $\mathrm{HbA}_{1 c}$. Additionally, our meta-analysis also showed a benefit of CGM on $\mathrm{HbA}_{1 c}$ change from baseline in children and adolescents. Results from all 8 studies providing specific data for the younger population were homogeneous, with consistently similar results. Moreover, the magnitude of the effect appeared to be very similar in both groups. These observations provide a new important insight into the discussion about the effect of CGM in different age groups, sug gesting that not only adults but also children and adolescents benefit from CGM use.

Two different CGM systems are available for patients: older retrospective and, with increasing frequency, newer real-time. The former model requires glucose data to be retrospectively reviewed after being downloaded from the device by physicians, while the latter provides instantaneous information about the patient's glucose values, allowing immediate self-adjustment of the insulin dose. Both of these systems are utilized therapeutically, serving to guide patient treatment and allowing physicians to successfully adjust insulin doses in order to provide adequate glycemic control. ${ }^{33,34}$ As proposed earlier by the Cochrane Metabolic and Endocrine Disorder Group, ${ }^{35}$ we included both systems in our initial meta-analysis, provided that retrospective measurements were also used to modify patient treatment and thus used both diagnostically and therapeutically. Subsequently, data were stratified to detect potential differences between the groups. Real-time CGM systems were observed to have an impact on $\mathrm{HbA}_{1 c}$ change from baseline as compared with SMBG. Conversely, retrospective CGM devices did not demonstrate statistical significance. However, there was no interaction between the subgroups, indicating that the effect size might be comparable for both real-time and retrospective designs. Nevertheless, our quantitative accumulation displayed a trend favoring retrospective CGM over SMBG. This trend was consistent between individual studies and could potentially achieve statistical significance with the addition of new evidence. One should also note that the evidence for the hypoglycemic episodes reduction 
was available for real-time CGM but not for retrospective systems.

The included trials differed with regard to continuity of glucose measurement. While both ongoing and intermittent approaches to glucose measurement seem to be equally effective in reducing $\mathrm{HbA}_{1 \mathrm{c}}$ levels, this finding should be treated with caution in the context of the specific cut-off point of $<6$ days and $\geq 6$ per week use. A favorable effect of CGM on the frequency of hypoglycemic episodes was shown only in trials applying an ongoing manner of blood glucose reading. On the other hand, the method of intermittent reading has the advantage of significantly reducing the cost of sensors ${ }^{36}$ and likely reducing discomfort associated with wearing the device.

CGM systems were generally well tolerated by patients and not associated with serious adverse events, particularly diabetic ketoacidosis. Reported adverse events were limited mainly to mild skin reactions occurring at the implantation site. However, the device can cause some difficulties in everyday activities, most commonly related to the size of the device. ${ }^{28,37,38}$

This paper is the first meta-analysis that comprehensively evaluates the efficacy and safety of the available CGM systems vs. SMBG in various subpopulations of type 1 diabetic patients and types of devices. In the past, a few systematic reviews were performed comparing these 2 interventions, but none of them answered the question about the efficacy of CGM in different clinical and technological settings. Golicki et al. ${ }^{39}$ searched medical databases up through June 2007 in order to find the RCTs enrolling children with type 1 diabetes. In their meta-analysis no significant improvement in $\mathrm{HbA}_{1 c}$ levels was shown in the CGM group. More recently, 3 systematic reviews were published evaluating the efficacy of CGM using exclusively real-time devices. Hoeks et al. ${ }^{9}$ reviewed 9 RCTs enrolling both type 1 and type 2 diabetic patients, but did not conduct a meta-analysis claiming clinical heterogeneity. They found 6 studies showing that real-time CGM could improve $\mathrm{HbA}_{1 \mathrm{c}}$ reduction by $0.3 \%$ to $0.7 \%$; however, only one of them clearly demonstrated a statistically significant benefit of CGM. Pickup et al. ${ }^{40}$ performed a meta-analysis of 6 trials using individual patient data and confirmed the benefit of real-time CGM systems over SMBG with regard to $\mathrm{HbA}_{1 c}$ decrease in the general type 1 diabetic population. These 2 studies analyzed the general population regardless of age and did not attempt to evaluate potential differences of the effect size in particular subsets of patients.

Our systematic review based on RCTs published throughout June 2011 included 8 studies for real-time CGM and 6 for retrospective CGM. Moreover, we evaluated not only differences between CGM and SMBG, but also the effect magnitude depending on different settings in blood glucose (type of CGM, continuity of glucose readings) and patient characteristic (age, glycemic control). Our review was limited by a lack of access to patient level data, thus we were only able to perform a subgroup analysis according to Cochrane Collaboration principles. After our analysis had already been accomplished, another systematic review was published by Gandhi et al., ${ }^{40}$ overlapping to some extent with the scope of our work, but characterized by several limitations influencing its results. First of all, the authors included trials representing different populations (type 1 and type 2 diabetes) and did not exclude noninvasive CGM systems. This led to a high level of heterogeneity and forced the authors to apply a random effect model reducing the credibility and increasing the imprecision of the results. As a consequence, they downgraded the strength of evidence to moderate just due to imprecision. In our study, we considered only type 1 diabetes and excluded noninvasive methods of CGM, thus receiving more precise results without substantial heterogeneity. Gandhi et al. ${ }^{40}$ also showed a strong effect of CGM in adult type $1 \mathrm{di}-$ abetic patients (WMD $-0.50[-0.69 ;-0.30]$ ) with a concomitant lack of benefit in pediatric patients (WMD -0.06 [-0.31; 0.18]). However, several problems that could have affected the results can be pointed out in their work. Firstly, they did not include the results presented by Hirsh et al., ${ }^{24}$ who reported minor CGM effect on $\mathrm{HbA}_{1 c}$ in type 1 diabetic adults. Secondly, they used data reported by O'Connell et al. ${ }^{26}$ for the entire population rather than stratified according to the age group. Moreover, it appears that the authors made a technical error during the inclusion of the study by Tamborlane et al., ${ }^{25}$ which depleted the efficacy of CGM in children population. Finally, Gandhi et $a .^{40}$ included a study for noninvasive CGM in pediatric patients, in which nonsignificant differences favoring the control group were reported. All these shortcomings could have resulted in an exaggerated CGM effect in adults with its concomitant depreciation in pediatric patients.

The current results are consistent with the previous findings and recommendations demonstrating glycemic control improvement in adults using CGM. ${ }^{25,33}$ However, according to our knowledge, this is the first report which proves that CGM systems improve glycemic control also in children and adolescents. Although the results of recent individual patient data meta-analysis showed that there was no correlation between age and $\mathrm{HbA}_{1 c}$ decrease, it was certainly insufficient to conclude about significance of the effect size in pediatric group. ${ }^{41}$ Our systematic search identified 8 studies that provide information regarding $\mathrm{HbA}_{1 c}$ decrease in more than 281 children and adolescents (TABLE 1). Five of these trials enrolled exclusively patients below 18 years of age. The remaining 3 studies also included adults; however, the reported data were stratified according to age so that they could be utilized in our meta-analysis. Moreover, these 3 studies were published after 2007 and therefore could not be included in the earlier meta-analysis. ${ }^{24-26}$ This new finding is of practical importance and may influence current clinical guidelines. 
In summary, CGM, particularly its real-time system, has a favorable effect on glycemic control and decreases the incidence of hypoglycemic episodes in both adult and pediatric type 1 diabetic patients.

Acknowledgements We would like to thank Katarzyna Kapcia for assistance in graphic design and Małgorzata Grzanka for help with study selection.

Contribution statement P. Wojciechowski: searching medical databases, protocol development, data analysis and interpretation, writing the manuscript. P. Ryś: protocol development, data analysis and interpretation, writing the manuscript. A. Lipowska: searching medical databases, study selection, data analysis, writing the manuscript. M. Gawęska: searching medical databases, study selection, data extraction and study assessment, data analysis, writing the manuscript. M.T. Małecki: interpretation of data, revising the article critically for important intellectual content, final approval of the version to be submitted. P. Wojciechowski and P. Ryś contributed equally to this work.

\section{REFERENCES}

1 DCCT Research Group. The effect of intensive treatment of diabetes on the development and progression of long-term complications in insulin-dependent diabetes mellitus. The Diabetes Control and Complications Trial Research Group. N Engl J Med. 1993; 329: 977-986.

2 Marshall SM, Flyvbjerg A. Prevention and early detection of vascula complications of diabetes. BMJ. 2006; 333: 475-480.

3 American Diabetes Association. Standards of medical care in diabetes 2010. Diabetes Care. 2009; 33 Supp 1: S11-S61.

4 Melki V, Ayon F, Fernandez M, Hanaire-Broutin H. Value and limitations of the Continuous Glucose Monitoring System in the management of type diabetes. Diabetes Metab. 2006; 32: 123-129.

5 Vaddiraju S, Burgess DJ, Tomazos I, et al. Technologies for continuous glucose monitoring: current problems and future promises. J Diabetes Sci Technol. 2010; 4: 1540-1562.

6 Medtronic MiniMed. History. http://www.minimed.com/about/history html. Accessed June 22, 2011.

7 Summary of safety and effectiveness data for the MiniMed Continuous Glucose Monitoring System (CGMS). PMA P980022, Food and Drug Administration [article online], 1999. http://www.accessdata.fda.gov/cdrh_docs/ pdf/P980022b.pdf. Accessed June 22, 2011.

8 Block JM. Continuous glucose monitoring: changing diabetes behavio in real time and retrospectively. J Diabetes Sci Technol. 2008; 2: 484-489.

9 Hoeks LB, Greven WL, de Valk HW. Real-time continuous glucose monitoring system for treatment of diabetes: a systematic review. Diabet Med. 2011; 28: 386-394

10 Raccah D, Sulmont V, Reznik Y, et al. Incremental value of continuous glucose monitoring when starting pump therapy in patients with poorly controlled type 1 diabetes: the RealTrend study. Diabetes Care. 2009; 32: 2245 2250 .

11 Jadad AR, Moore RA, Carroll D, et al. Assessing the quality of reports of randomized clinical trials: is blinding necessary? Control Clin Trials. 1996; 17: 1-12.

12 Cohen J. The Effect Size Index: d. In: Cohen J, ed. Statistical Power Analysis for the Behavioral Sciences. 2nd ed. New Jersey: Lawrence Erlbaum Associates; 1988: 20-26.

13 Higgins JPT, Green S, eds. Cochrane Handbook for Systematic Reviews of Interventions Version 5.1.0 [updated March 2011]. The Cochrane Collaboration, 2011. http://www.cochrane-handbook.org.

14 British Society for Paediatric Endocrinology and Diabetes. Continuous glucose monitoring: consensus statement on the use of glucose sensing in outpatient clinical diabetes care. http://www.bsped.org.uk /professional/guide lines/docs/ContinuousGlucoseMonitoring.pdf. Accessed July 12, 2011.

15 Borenstein M, Hedges LV, Higgins JPT, Rothstein HR, eds. Introduction to Meta-Analysis. Chichester, United Kingdom: John Wiley \& Sons, Ltd; 2009.

16 Chase HP, Kim LM, Owen SL, et al. Continuous subcutaneous glucose monitoring in children with type 1 diabetes. Pediatrics. 2001; 107: 222-226.
17 Chico $A$, Vidal-Ríos $P$, Subirà $M$, Novials $A$. The continuous glucose monitoring system is useful for detecting unrecognized hypoglycemias in patients with type 1 and type 2 diabetes but is not better than frequent cap illary glucose measurements for improving metabolic control. Diabetes Care. 2003; 26: 1153-1157.

18 Ludvigsson J, Hanas R. Continuous subcutaneous glucose monitoring improved metabolic control in pediatric patients with type 1 diabetes: a controlled crossover study. Pediatrics. 2003; 111: 933-938.

19 Deiss D, Hartmann R, Schmidt J, Kordonouri O. Results of a randomised controlled cross-over trial on the effect of continous subcutaneous glucose monitoring (CGMS) on glycaemic control in children and adolescents with type 1 diabetes. Exp Clin Endocrinol Diabetes. 2006; 114: 63-67.

20 Lagarde WH, Barrows FP, Davenport ML, et al. Continuous subcutaneous glucose monitoring in children with type 1 diabetes mellitus: a single-blind, randomized, controlled trial. Pediatr Diabetes. 2006; 7: 159-164.

21 Yates K, Hasnat Milton A, Dear K, Ambler G. Continuous glucose monitoring-guided insulin adjustment in children and adolescents on near-physiological insulin regimens: a randomized controlled trial. Diabetes Care. 2006; 29: 1512-1517.

22 Deiss D, Bolinder J, Riveline JP, et al. Improved glycemic control in poorly controlled patients with type 1 diabetes using real-time continuous glucose monitoring. Diabetes Care. 2006; 29: 2730-2732.

23 JDRF CGM Study Group. JDRF randomized clinical trial to assess the efficacy of real-time continuous glucose monitoring in the management of type 1 diabetes: research design and methods. Diabetes Technol Ther. 2008; 10: 310-321

24 Hirsch IB, Abelseth J, Bode BW, et al. Sensor-augmented insulin pump therapy: results of the first randomized treat-to-target study. Diabetes Technol Ther. 2008; 10: 377-383.

25 Tamborlane WV, Beck RW, Bode BW, et al. Continuous glucose monitoring and intensive treatment of type 1 diabetes. N Engl J Med. 2008; 359: 1464-1476.

26 0'Connell MA, Donath S, O'Neal DN, et al. Glycaemic impact of patient-led use of sensor-guided pump therapy in type 1 diabetes: a randomised controlled trial. Diabetologia. 2009; 52: 1250-1257.

27 Beck RW, Hirsch IB, Laffel L, et al. The effect of continuous glucose monitoring in well-controlled type 1 diabetes. Diabetes Care. 2009; 32 1378-1383.

28 Cosson E, Hamo-Tchatchouang E, Dufaitre-Patouraux L, et al. Multicentre, randomised, controlled study of the impact of continuous sub-cutaneous glucose monitoring (GlucoDay) on glycaemic control in type 1 and type 2 diabetes patients. Diabetes Metab. 2009; 35: 312-318.

29 Battelino T, Phillip M, Bratina N, et al. Effect of continuous glucose monitoring on hypoglycemia in type 1 diabetes. Diabetes Care. 2011; 34 $795-800$

30 The Writing Team for the Diabetes Control and Complications Trial/Epidemiology of Diabetes Interventions and Complications Research Group. Effect of intensive therapy on the microvascular complications of type 1 diabetes mellitus. JAMA. 2002; 287: 2563-2569.

31 Unger J, Parkin C. Hypoglycemia in insulin-treated diabetes: a case for increased vigilance. Postgrad Med. 2011; 123: 81-91.

32 Rubin DJ, Rybin D, Doros G, McDonnell ME. Weight-based, insulin dose-related hypoglycemia in hospitalized patients with diabetes. Diabetes Care. 2011; 34: 1723-1728.

33 Blevins TC, Bode BW, Garg SK, et al. Statement by the American Association of Clinical Endocrinologists Consensus Panel on continuous glucose monitoring. Endocr Pract. 2010; 16: 730-745.

34 Block J. Prospective vs retrospective CGM - clinical application and utility. 40th Annual Meeting of the EASD; 2005; Athens.

35 Langendam MW, Hooft L, De Vries $\mathrm{H}$, et al. Continuous glucose monitoring systems for type 1 diabetes mellitus (Protocol). Cochrane Database of Systematic Reviews. 2009; 4 (CD008 101):

36 Burge MR, Mitchell S, Sawyer A, et al. Continuous glucose monitoring the future of diabetes management. Diabetes Spectr. 2008; 21: 112-119.

37 Cemeroglu AP, Stone R, Kleis $L$, et al. Use of a real-time continuous glucose monitoring system in children and young adults on insulin pump therapy: patients' and caregivers' perception of benefit. Pediatr Diabetes. 2010; 11: 182-187.

38 Kubiak T, Wörle B, Kuhr B, et al. Microdialysis-based 48-hour continuous glucose monitoring with GlucoDay: clinical performance and patients acceptance. Diabetes Technol Ther. 2006; 8: 570-575.

39 Golicki DT, Golicka D, Groele L, Pankowska E. Continuous Glucose Monitoring System in children with type 1 diabetes mellitus: a systematic review and meta-analysis. Diabetologia. 2008; 51: 233-240.

40 Gandhi GY, Kovalaske M, Kudva Y, et al. Efficacy of continuous glucose monitoring in improving glycemic control and reducing hypoglycemia: a systematic review and meta-analysis of randomized trials. J Diabetes Sci Technol. 2011 5: 952-965.

41 Pickup JC, Freeman SC, Sutton AJ. Glycaemic control in type 1 diabetes during real time continuous glucose monitoring compared with self monitoring of blood glucose: meta-analysis of randomised controlled trials using individual patient data. BMJ. 2011; 343: d3805. 


\title{
Skuteczność i bezpieczeństwo ciągłego monitorowania glikemii w porównaniu
} z samokontrolą poziomu glukozy we krwi u chorych na cukrzycę typu 1

\author{
Przegląd systematyczny i metaanaliza
}

\author{
Piotr Wojciechowski ${ }^{1}$, Przemysław Ryś ${ }^{1}$, Anna Lipowska ${ }^{2,3}$, \\ Magdalena Gawęska', Maciej T. Małecki ${ }^{3,4}$ \\ 1 HTA Consulting, Kraków \\ 2 Emory University School of Medicine, Atlanta, Georgia, Stany Zjednoczone \\ 3 Katedra Chorób Metabolicznych, Uniwersytet Jagielloński, Collegium Medicum, Kraków \\ 4 Klinika Chorób Metabolicznych, Szpital Uniwersytecki w Krakowie, Kraków
}

\section{SŁOWA KLUCZOWE}

ciągłe monitorowanie glikemii, cukrzyca typu 1, metaanaliza, przegląd systematyczny
Adres do korespondencji: prof. dr hab. med. Maciej T. Małecki, Katedra Chorób Metabolicznych, Uniwersytet Jagielloński, Collegium Medicum, ul. Kopernika 15,

31-501 Kraków, Polska,

tel.: 12-424-83-05, fax: 12-421-97-86, e-mail: malecki malecki@yahoo.com Praca wpłynęta: 03.09.2011. Przyjęta do druku: 28.09.2011. Zgłoszono sprzeczność interesów: Przemysław Ryś otrzymywał wynagrodzenie za konsultacje od firmy Medtronic, producenta systemów CGM

Pol Arch Med Wewn. 2011; 121 (10): 333-344

Copyright by Medycyna Praktyczna, Kraków 2011

\section{STRESZCZENIE}

WPROWADZENIE Samokontrola poziomu glukozy (self-monitoring of blood glucose - SMBG) jest istotnym elementem terapii chorych na cukrzycę typu 1, aczkolwiek może nie zapewniać właściwego wyrównania metabolicznego. Nową, alternatywną metodą jest ciągłe monitorowanie glikemii (continuous glucose monitoring - CGM), które pozwala uzyskać jej lepszą kontrolę. Wyniki badań klinicznych porównujących CGM z SMBG są jednak niejednoznaczne.

CELE Celem niniejszej publikacji była ocena skuteczności i bezpieczeństwa różnych systemów CGM w porównaniu z SMBG w oparciu o przegląd systematyczny oraz metaanalizę.

METODY Przeszukano najważniejsze bazy informacji medycznej do czerwca 2011 w celu identyfikacji randomizowanych badań klinicznych porównujących CGM z SMBG u chorych na cukrzycę typu 1. Kryteria włączenia spetniały badania trwające co najmniej 12 tygodni. Średnia ważona różnica (weighted mean difference - WMD) lub standaryzowana średnia różnica (standardized mean difference - SMD) zostały obliczone dla wartości ciągłych, natomiast dane dychotomiczne przedstawiono w postaci ilorazu szans (odds ratio - OR) lub ryzyka względnego.

WYNIKI Zidentyfikowano 14 badań obejmujących łącznie 1268 chorych na cukrzycę typu 1, z których 670 przydzielono do grupy CGM, a 598 do grupy SMBG. U chorych stosujących CGM nastąpita istotnie większa redukcja poziomu hemoglobiny $A_{1 c}\left(\mathrm{Hb}_{1 \mathrm{c}}\right)$ w porównaniu z osobami stosującymi SMBG (WMD $-0,26 \%[-0,34 ;-0,19])$. Wielkość efektu była porównywalna w podgrupie obejmującej dzieci i młodzież (WMD $-0,25 \%[-0,43 ;-0,08]$ ) i u dorosłych (WMD $-0,33 \%[-0,46 ;-0,2])$. Przewagę CGM nad SMBG potwierdzono tylko w przypadku systemów CGM pracujących w czasie rzeczywistym (WMD -0,27\% $[-0,34 ;-0,19])$. W grupie CGM większy był odsetek chorych, u których wartość $\mathrm{HbA}_{1 \mathrm{c}}$ uległa zmniejszeniu do wartości docelowych (OR 2,14 $[1,41 ; 3,26])$. Kumulacja ilościowa 4 badań wykazała redukcję częstości epizodów hipoglikemii w grupie CGM (SMD -0,32 [-0,52; -0,13]).

wNIOSKI Systemy CGM, szczególnie pracujące w czasie rzeczywistym, wykazują korzystny wpływ na wyrównanie glikemii oraz redukcję incydentów hipoglikemii zarówno u dorosłych, jak i u dzieci z cukrzycą typu 1. 